\title{
Correlation of ERK/MAPK signaling pathway with proliferation and apoptosis of colon cancer cells
}

\author{
GANG ZHOU, JING YANG and PENG SONG
}

Department of Medical Oncology, The Second Medical Centre, Chinese PLA General Hospital, Beijing 100853, P.R. China

Received April 9, 2018; Accepted October 26, 2018

DOI: $10.3892 / \mathrm{ol} .2018 .9857$

\begin{abstract}
The role of extracellular signal-regulated kinase/mitogen-activated protein kinase (ERK/MAPK) signaling pathway in the proliferation and apoptosis of human colon cancer cells was studied. The transduction process of ERK/MAPK signaling pathway was inhibited using methyl ethyl ketone (MEK) inhibitor U0126. Promoting effect of hepatocyte growth factor (HGF) on proliferation of human colon cancer cells was detected via Cell Counting Kit 8 (CCK8), the cycle and apoptosis of human colon cancer cells were detected via flow cytometry, and the migration of human colon cancer cells was detected via wound healing assay. The results revealed that after drug treatment for $48 \mathrm{~h}$, there were statistically significant differences in 4 and $8 \mu \mathrm{mol} / 1 \mathrm{U} 0126$ experimental group compared with control group $(\mathrm{P}<0.05)$. Compared with those in control group, G1 phase, $\mathrm{S}$ phase, G2 phase and proliferation index (PI) in 2, 4 and $8 \mu \mathrm{mol} / 1$ U0126 group had statistically significant differences $(\mathrm{P}<0.05)$. There were statistically significant differences in comparison of G1 phase, S phase, G2 phase and PI between control and $8 \mu \mathrm{mol} / 1 \mathrm{U} 0126$ group $(\mathrm{P}<0.05)$. Compared with that in control group, the cell migration distance in $8 \mu \mathrm{mol} / 1$ U0126 group had a statistically significant difference after drug treatment for $24 \mathrm{~h}(\mathrm{P}<0.05)$. After drug treatment for 48 and $72 \mathrm{~h}$, the cell migration distance in 4 and $8 \mu \mathrm{mol} / 1$ U0126 group was significantly reduced, and the differences were statistically significant compared with that in control group $(\mathrm{P}<0.05)$. In conclusion, ERK/MAPK signaling pathway is involved in the effects of HGF of promoting proliferation and regulating cell cycle and apoptosis of human colon cancer cells, providing a new approach for the treatment of colon cancer.
\end{abstract}

Correspondence to: Dr Gang Zhou, Department of Medical Oncology, The Second Medical Centre, Chinese PLA General Hospital, 28 Fuxing Road, Beijing 100853, P.R. China E-mail: kuangbu139@163.com

Key words: extracellular signal-regulated kinase/mitogen-activated protein kinase, colon cancer, cell proliferation, apoptosis

\section{Introduction}

Colon cancer is a common malignant tumor in the digestive system. In recent years, the incidence rate of colon cancer has gradually increased and the 5-year survival rate is still not high. Patients with colon cancer often die of tumor recurrence and metastasis (1). At present, the mechanisms of occurrence and development of colon cancerare not completely understood. Hepatocyte growth factor (HGF) is a factor in vivo with multiple biological functions, which strongly promotes cell division, inducing epithelial cell migration, invasion and angiogenesis in vivo (2,3). Setia et al (4) found that the HGF expression is significantly increased in patients with colon cancer, and it is even higher in patients complicated with metastasis, so it is believed that HGF is involved in growth and metastasis processes of colon cancer. HGF can bind to c-methionine (c-Met) receptor and activates its activity, thus resulting in tyrosine phosphorylation of various substrate proteins, including phospholipase C- $\gamma$ (PLC- $\gamma$ ), phosphatidylinositol 3-kinase-serine/threonine kinase/protein kinase B (PI3K-AKT/PKB), mitogen-activated protein kinase (MAPK) and Grb2-associated binder-1 (Gab1) $(5,6)$. MAPK participates in the physiological functions of various cells in vivo, including in proliferation, apoptosis and differentiation (7). In this study, methyl ethyl ketone (MEK) inhibitor U0126 was used to inhibit the extracellular signal-regulated kinase (ERK)/MAPK signal transduction pathway, so as to explore the roles of ERK/MAPK signaling pathway in the effects of HGF on promoting proliferation, and regulating cycle and apoptosis of human colon cancer cells to find new therapeutic approaches of colon cancer.

\section{Materials and methods}

Materials. Human colon cancer SW620 cells were purchased from Beijing Beina Chuanglian Biotechnology Research Institute (cat. no. BNCC337664, Beijing, China). Cells were cultured using Roswell Park Memorial Institute (RPMI)-1640 medium and $15 \%$ fetal bovine serum (FBS) in an incubator with $5 \% \mathrm{CO}_{2}$ at $37^{\circ} \mathrm{C}$. Cells were cryopreserved using basal medium, 5\% dimethyl sulfoxide (DMSO) and 15\% FBS, and those in logarithmic growth phase were used for subsequent experiments.

Reagents: Roswell Park Memorial Institute (RPMI)-1640 (Hyclone; GE Healthcare Life Sciences; Logan, UT, USA), 
Table I. Inhibition rate of U0126 on colon cancer cell proliferation.

\begin{tabular}{llc}
\hline Variables & \multicolumn{1}{c}{ OD } & $\begin{array}{c}\text { Inhibition } \\
\text { rate }(\%)\end{array}$ \\
\hline Control & $0.16121 \pm 0.021294$ & - \\
$\mathrm{DMSO}$ & $0.15374 \pm 0.013859^{\mathrm{a}}$ & - \\
$0.5 \mu \mathrm{mol} / 1 \mathrm{U} 0126$ & $0.15194 \pm 0.014857^{\mathrm{a}}$ & - \\
$1 \mu \mathrm{mol} / 1 \mathrm{U} 0126$ & $0.14982 \pm 0.020958^{\mathrm{a}}$ & - \\
$2 \mu \mathrm{mol} / 1 \mathrm{U} 0126$ & $0.13957 \pm 0.031857^{\mathrm{a}}$ & - \\
$4 \mu \mathrm{mol} / 1 \mathrm{U} 0126$ & $0.12194 \pm 0.015392^{\mathrm{b}}$ & 24.7 \\
$8 \mu \mathrm{mol} / 1 \mathrm{U} 0126$ & $0.11482 \pm 0.005928^{\mathrm{b}, \mathrm{c}}$ & 28.9 \\
\hline
\end{tabular}

${ }^{\mathrm{a}} \mathrm{P}>0.05,{ }^{\mathrm{b}} \mathrm{P}<0.05$ vs. control group. ${ }^{\mathrm{c}} \mathrm{P}>0.05$ vs. $4 \mu \mathrm{mol} / \mathrm{l} \mathrm{U} 0126$ group. OD, optical density; DMSO, dimethyl sulfoxide.

Dimethyl sulfoxide (DMSO) (Beyotime, Shanghai, China), FBS, $0.25 \%$ trypsin (both from Thermo Fisher Scientific, Inc., Waltham, MA, USA), Cell Counting Kit 8 (CCK8; Shanghai Yubo Biological Technology Co., Ltd., Shanghai, China), Annexin V-fluorescein isothiocyanate (FITC) apoptosis detection kits, polyclonal antibodies (all from BD Pharmingen; BD Biosciences, Franklin Lakes, NJ, USA), and MAPK MEK1/2 efficient selective inhibitor U0126 (Shanghai Yeasen Biological Technology Co., Ltd., Shanghai, China).

The study was approved by the Ethics Committee of Chinese PLA General Hospital (Beijing, China).

\section{Methods}

Detection of effect of U0126 on SW620 cell proliferation via CCK8. In this experiment, cells were divided into seven groups, including five experimental groups (U0126: $0.5,1,2,4$ and $8 \mu \mathrm{mol} / 1$, respectively $+\mathrm{HGF})$, the control group (+ HGF) and the DMSO group. Each group had five repeated wells, and HGF was added into each group after cell culture for $30 \mathrm{~min}$ and after culture for another $48 \mathrm{~h}$, $10 \mu 1$ CCK8 reagent was dropwise added into each well, followed by incubation in the dark for $2 \mathrm{~h}$. The optical density (OD) value of each well was detected using a Sunrise microplate reader (Tecan Group, Ltd., Mannedorf, Switzerland) at a wavelength of $570 \mathrm{~nm}$. Inhibition rate $=\left(\mathrm{OD}_{\text {control group }}-\mathrm{OD}_{\mathrm{U} 0126 \text { group }}\right) / \mathrm{OD}_{\text {control group }} \mathrm{x} 100 \%$.

Detection of cell cycle and apoptosis via flow cytometry. Cells were cultured, collected, and fixed at $4{ }^{\circ} \mathrm{C}$ for at least $24 \mathrm{~h}$. The fixing solution was removed before use, and cells were washed with phosphate-buffered saline (PBS). The cell density was adjusted to $1.0 \times 10^{6} / \mathrm{ml}$. A total of $0.1 \mathrm{ml}$ cell suspension was taken, added with $1 \mathrm{ml}$ propidium iodide dye liquor for staining in the dark at $4^{\circ} \mathrm{C}$ for half an hour and filtered. The cell cycle and apoptosis were detected on the flow cytometer (Thermo Fisher Scientific, Inc., Waltham, MA, USA). Multicycle AV software (De Novo Software, Glendale, CA, USA) was used to analyze the DNA cell cycle, and the distribution percentage of each time phase in DNA histogram was calculated. The cell proliferative activity was presented as proliferation index (PI): $\mathrm{PI}=(\mathrm{S}+\mathrm{G} 2 / \mathrm{M}) /(\mathrm{G} 0 / \mathrm{G} 1+\mathrm{S}+\mathrm{G} 2 / \mathrm{M}) \times 100 \%$.

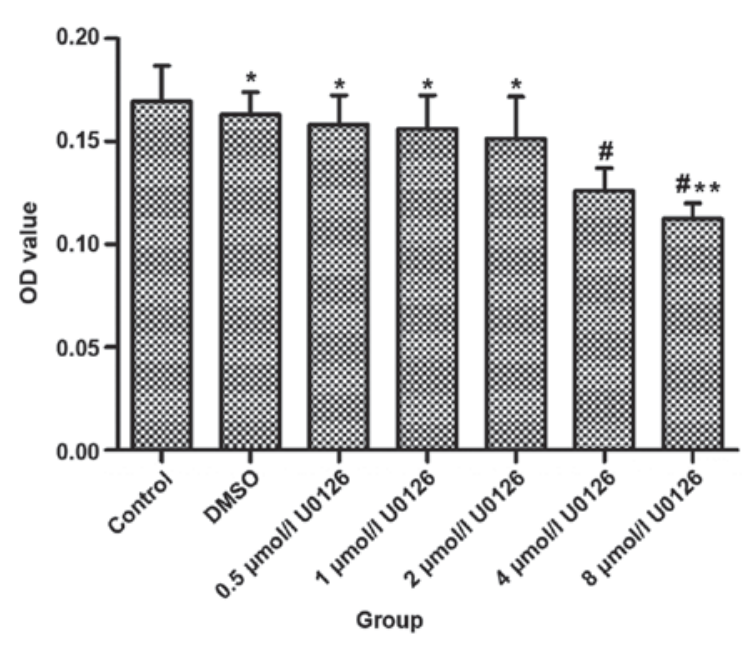

Figure 1. Inhibition rate of U0126 on colon cancer cell proliferation. ${ }^{*} \mathrm{P}>0.05$ and ${ }^{\#} \mathrm{P}<0.05$, compared to control group; ${ }^{* *} \mathrm{P}>0.05$, compared with $4 \mu \mathrm{mol} / 1$ U0126 group.

Detection of cell migration via wound healing assay. Cells were inoculated and cultured at a density of $2 \times 10^{6} /$ well. After $8 \mathrm{~h}$, the culture plate was scratched vertically using a spearhead, 6 scratches/well. After the plate was washed with PBS, complete medium was added into control group, $0.1 \%$ DMSO was added into DMSO group, and 4 and $8 \mu \mathrm{mol} / \mathrm{l}$ U0126 was added into experimental group. After half an hour, $20 \mathrm{ng} / 1$ HGF was added, and cell growth $(0 \mathrm{~h})$ was observed under a light microscope (x100) (Nikon Instrument Inc., NY, USA). The width of 3 scratches was measured using Image-Pro Plus (Media Cybernetics, Inc., Rockville, MD, USA), and cells continued to be cultured. After $24 \mathrm{~h}$, the complete medium was replaced, each group was added with the above-mentioned corresponding reagents, and cell migration distance was observed and measured under the light microscope: Migration distance $(\mathrm{d})=($ scratch width at $0 \mathrm{~h}-$ scratch width at $24 \mathrm{~h}) / 2$. Cells continued to be cultured, the complete medium was replaced after $48 \mathrm{~h}$, and cell migration distance was observed and measured under the light microscope: Migration distance $(\mathrm{d})=($ scratch width at $0 \mathrm{~h}-$ scratch width at $48 \mathrm{~h}) / 2$. Cells continued to be cultured until $72 \mathrm{~h}$. Inhibition rate of migration distance $=\left(\mathrm{d}_{\text {control group }}-\mathrm{d}_{\mathrm{U} 0126 \text { group }}\right) / \mathrm{d}_{\text {control group }} \mathrm{x} 100 \%$.

Statistical analysis. Statistical Product and Service Solutions (SPSS) 20.0 software (SPSS, Inc., Chicago, IL, USA) was used for statistical analysis. Measurement data were presented as mean \pm standard deviation (SD), one-way analysis of variance (ANOVA) was used for quantitative data, and Student-Newman-Keuls (SNK)-q test was used for multiple comparisons as a post hoc test. $\alpha=0.05$ indicated the inspection level.

\section{Results}

Detection of colon cancer cell proliferation via CCK8. After drug treatment for $48 \mathrm{~h}$, there were statistically significant differences in 4 and $8 \mu \mathrm{mol} / 1 \mathrm{U} 0126$ experimental group compared with control group $(\mathrm{P}<0.05)$. The inhibition rate had no significant difference between 4 and $8 \mu \mathrm{mol} / 1 \mathrm{U} 0126$ in experimental group ( $\mathrm{P}>0.05)$ (Table I and Fig. 1). 
Table II. Cell cycle and apoptosis (mean \pm SD).

\begin{tabular}{|c|c|c|c|c|c|}
\hline Variables & G1 & $\mathrm{S}$ & G2 & PI & Apoptosis \\
\hline Control & $51.05 \pm 8.59$ & $36.28 \pm 9.42$ & $12.39 \pm 15.37$ & $48.03 \pm 8.21$ & $0.94 \pm 0.13$ \\
\hline $0.5 \mu \mathrm{mol} / 1 \mathrm{U} 0126$ & $57.13 \pm 7.02^{\mathrm{b}}$ & $31.98 \pm 5.38^{\mathrm{b}}$ & $10.35 \pm 10.48^{b}$ & $44.32 \pm 7.41^{\mathrm{b}}$ & $1.17 \pm 0.36^{\mathrm{b}}$ \\
\hline $1 \mu \mathrm{mol} / 1 \mathrm{U} 0126$ & $62.77 \pm 3.84^{\mathrm{b}}$ & $28.13 \pm 3.06^{\mathrm{b}}$ & $9.04 \pm 2.14^{\mathrm{b}}$ & $37.46 \pm 3.77^{\mathrm{b}}$ & $1.03 \pm 0.11^{\mathrm{b}}$ \\
\hline $2 \mu \mathrm{mol} / 1 \mathrm{U} 0126$ & $68.02 \pm 6.62^{\mathrm{a}}$ & $22.17 \pm 4.18^{\mathrm{a}}$ & $10.95 \pm 3.19^{a}$ & $32.81 \pm 6.52^{\mathrm{a}}$ & $1.15 \pm 0.19^{b}$ \\
\hline $4 \mu \mathrm{mol} / 1 \mathrm{U} 0126$ & $76.35 \pm 4.06^{\mathrm{a}}$ & $16.02 \pm 3.86^{\mathrm{a}}$ & $8.49 \pm 4.13^{\mathrm{a}}$ & $23.05 \pm 4.22^{\mathrm{a}}$ & $1.09 \pm 0.13^{b}$ \\
\hline $8 \mu \mathrm{mol} / 1 \mathrm{U} 0126$ & $80.14 \pm 5.27^{\mathrm{a}}$ & $12.44 \pm 4.26^{\mathrm{a}}$ & $7.15 \pm 2.74^{\mathrm{a}}$ & $20.57 \pm 5.07^{\mathrm{a}}$ & $1.37 \pm 0.35^{\mathrm{b}}$ \\
\hline
\end{tabular}

${ }^{\mathrm{a}} \mathrm{P}<0.05,{ }^{\mathrm{b}} \mathrm{P}>0.05$ vs. control group. $\mathrm{PI}$, proliferation index.

Table III. Effect of drug on inhibition rate of cell migration (mean $\pm \mathrm{SD}$ ).

\begin{tabular}{|c|c|c|c|c|c|c|}
\hline \multirow[b]{2}{*}{ Variables } & \multicolumn{2}{|r|}{$24 \mathrm{~h}$} & \multicolumn{2}{|r|}{$48 \mathrm{~h}$} & \multicolumn{2}{|r|}{$72 \mathrm{~h}$} \\
\hline & $\mathrm{d}(\mu \mathrm{m})$ & $\begin{array}{c}\text { Migration } \\
\text { inhibition rate }(\%)\end{array}$ & $\mathrm{d}(\mu \mathrm{m})$ & $\begin{array}{c}\text { Migration } \\
\text { inhibition rate }(\%)\end{array}$ & $\mathrm{d}(\mu \mathrm{m})$ & $\begin{array}{c}\text { Migration } \\
\text { inhibition rate }(\%)\end{array}$ \\
\hline Control & $34.9 \pm 14.3$ & - & $47.2 \pm 9.4$ & - & $50.2 \pm 14.4$ & - \\
\hline DMSO & $31.5 \pm 11.7^{b}$ & - & $40.8 \pm 9.9^{b}$ & - & $52.6 \pm 18.2^{\mathrm{b}}$ & - \\
\hline $4 \mu \mathrm{mol} / 1 \mathrm{U} 0126$ & $19.9 \pm 7.2^{\mathrm{b}}$ & - & $25.3 \pm 15.4^{\mathrm{a}}$ & 46.2 & $28.6 \pm 15.1^{\mathrm{a}}$ & 44.7 \\
\hline $8 \mu \mathrm{mol} / 1 \mathrm{U} 0126$ & $13.8 \pm 6.2^{\mathrm{a}}$ & 61.1 & $18.4 \pm 6.1^{\mathrm{a}, \mathrm{c}}$ & 61.4 & $23.4 \pm 10.7^{\mathrm{a}, \mathrm{c}}$ & 54.1 \\
\hline
\end{tabular}

${ }^{\mathrm{a}} \mathrm{P}<0.05,{ }^{\mathrm{b}} \mathrm{P}>0.05$ vs. control group. ${ }^{\mathrm{c}} \mathrm{P}>0.05$ vs. $4 \mu \mathrm{mol} / \mathrm{l} \mathrm{U} 0126$ group. $\mathrm{d}$, migration distance; DMSO, dimethyl sulfoxide.

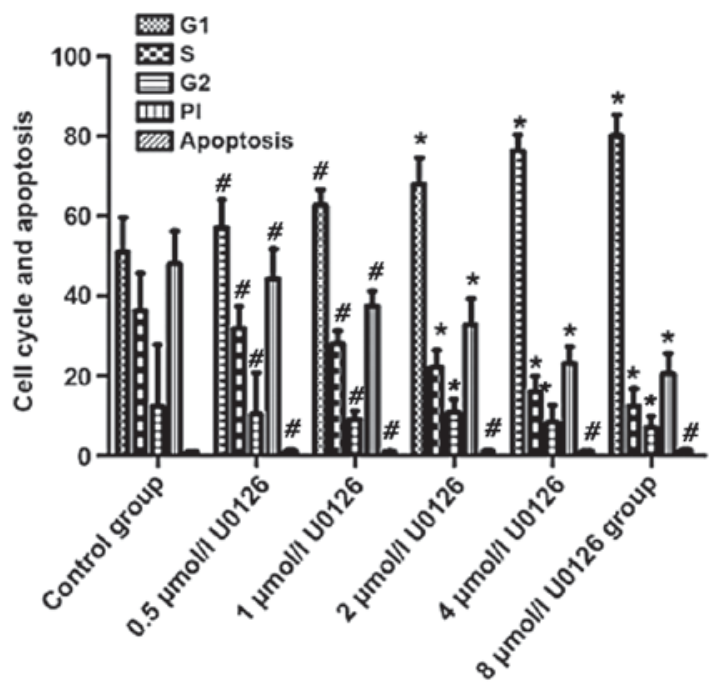

Figure 2. Effects of drugs on colon cancer cell cycle and apoptosis. Compared to control group, ${ }^{*} \mathrm{P}<0.05 ;{ }^{*} \mathrm{P}>0.05$.

Detection of cell cycle and apoptosis via flow cytometry. Compared with those in control group, G1 phase, S phase, G2 phase and PI in 2, 4 and $8 \mu \mathrm{mol} / 1$ U0126 group had statistically significant differences $(\mathrm{P}<0.05)$. G1 phase, $\mathrm{S}$ phase, G2 phase and PI in control and $8 \mu \mathrm{mol} / 1$ U0126 group were $51.05 \pm 8.59$ vs. $80.14 \pm 5.27 \%, 36.28 \pm 9.42$ vs. $12.44 \pm 4.26 \%$, $12.39 \pm 15.37$ vs. $7.15 \pm 2.74 \%$, and $48.03 \pm 8.21$ vs. $20.57 \pm 5.07 \%$, respectively, and differences were statistically significant $(\mathrm{P}<0.05)$ (Table II, Fig. 2).

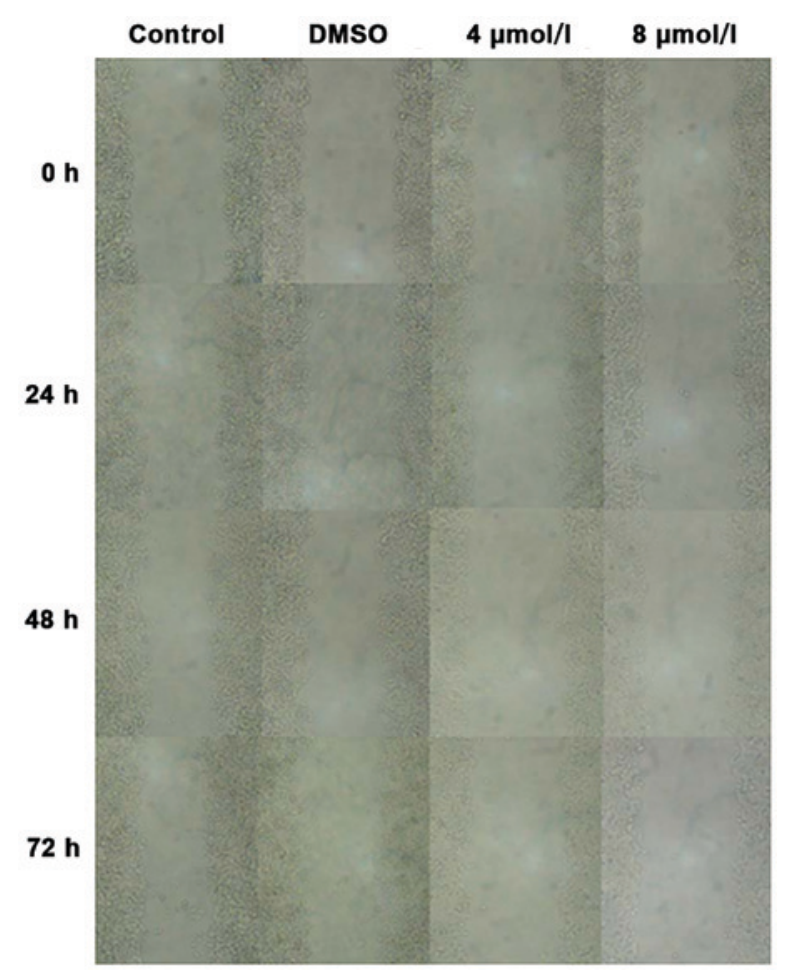

Figure 3. Detection of cell migration via wound healing assay.

Detection of cell migration via wound healing assay. After drug treatment for $24 \mathrm{~h}$, compared with that in control group, the cell migration distance in $8 \mu \mathrm{mol} / 1 \mathrm{U} 0126$ group had a statistically significant difference $(\mathrm{P}<0.05)$, but it had no significant 
difference between DMSO and $4 \mu \mathrm{mol} / 1 \mathrm{U} 0126$ group ( $\mathrm{P}>0.05)$. After drug treatment for 48 and $72 \mathrm{~h}$, the cell migration distance in 4 and $8 \mu \mathrm{mol} / 1 \mathrm{U} 0126$ group was significantly reduced, and the differences were statistically significant compared with those in control group $(\mathrm{P}<0.05)$. However, the cell migration distance had no statistically significant difference between 4 and $8 \mu \mathrm{mol} / 1$ U0126 group (P>0.05) (Fig. 3, Table III).

\section{Discussion}

The incidence rate of colon cancer is increasing year by year, seriously threatening human health. The widely-used treatment means is surgery, and the postoperative 5-year survival rate of patients is also different due to different staging of colon cancer. The 5-year survival rate of patients in Dukes A stage is $>90 \%$, but that of patients in Dukes C stage is only $50 \%$ (8). Although the 5-year survival rate of patients can be increased to some extent through vaious comprehensive treatments, the prognosis is still unsatisfactory. Tumor recurrence and metastasis are still primary causes of patients' death (9), and these factors are closely related to the proliferation and invasion capacities of tumor cells.

In a variety of tissues in the human body, there is an extracellular signal factor, namely HGF, and it is essentially a polypeptide growth factor (10). HGF can be expressed and secreted in normal human and tumor cells. Some scholars found via experiments that HGF can effectively promote the proliferation and invasion processes of SW620 cells in vitro (11). ERK/MAPK signaling pathway is involved in a variety of physiological cell functions, such as proliferation, differentiation and apoptosis. These functions of tumor cells are also associated with the ERK/MAPK signal transduction pathway (12). Radziwon-Balicka et al (13) found that MEK phosphorylation level is overexpressed in villous adenoma tissues, and its expression is significantly increased compared with that in para-carcinoma tissues and normal tissues. Lee et al (14) also found similar results in tubular adenomas. HGF binds to c-Met receptor in vivo and activates its kinase activity and multiple downstream signaling pathways, including ERK/MAPK (15), which provides a new idea for inhibiting ERK/MAPK signaling pathway to block the effects of HGF on promoting proliferation and invasion of colon cancer cells. Enayat et al (16) showed that inhibiting ERK/MAPK signal transduction pathway can produce more significant inhibitory effects on proliferation and invasion of tumor cells.

In this study, after drug treatment for $48 \mathrm{~h}$, there were statistically significant differences in 4 and $8 \mu \mathrm{mol} / 1 \mathrm{U} 0126$ experimental group compared with control group $(\mathrm{P}<0.05)$. The inhibition rate had no significant difference between the experimental groups of 4 and $8 \mu \mathrm{mol} / 1 \mathrm{U} 0126$ ( $\mathrm{P}>0.05)$, and the tumor cell proliferation was not inhibited in DMSO, 0.5, 1 and $2 \mu \mathrm{mol} / 1 \mathrm{U} 0126$ groups. The above results suggest that inhibiting ERK/MAPK signaling pathway can effectively block the ability of HGF to promote tumor cell proliferation, but there is no concentration-dependent effect. This is consistent with the results of Chen et al (17). It is speculated that the possible reason is that there are other downstream signaling pathways in HGF, such as PLC- $\gamma$ and PI3K/AKT, directly leading to no dose-dependence in inhibition effect.

Results of flow cytometry showed that U0126 inhibited the cell cycle from entering S phase, and U0126 had no obvious effect on apoptosis of colon cancer cells. However, Bodur et al (18) found that inhibiting ERK/MAPK signaling pathway can promote apoptosis. It is speculated that the application of U0126 cannot completely antagonize the effect of HGF of inhibiting tumor cell apoptosis, and ERK/MAPK signal transduction pathway does not play a major role in regulating the apoptosis of colon cancer SW620 cells.

Wound healing assay showed that after drug treatment for $24 \mathrm{~h}$, compared with that in control group, the cell migration distance in $8 \mu \mathrm{mol} / 1 \mathrm{U} 0126$ group had a statistically significant difference $(\mathrm{P}<0.05)$, but it had no significant difference between DMSO and $4 \mu \mathrm{mol} / 1 \mathrm{U} 0126$ group ( $\mathrm{P}>0.05)$. After drug treatment for 48 and $72 \mathrm{~h}$, the cell migration distance in 4 and $8 \mu \mathrm{mol} / 1 \mathrm{U} 0126$ group was significantly reduced, and the differences were statistically significant compared with those in control group $(\mathrm{P}<0.05)$. However, the cell migration distance had no statistically significant difference between 4 and $8 \mu \mathrm{mol} / 1 \mathrm{U} 0126$ group ( $\mathrm{P}>0.05)$. These results indicate that inhibiting ERK/MAPK signal transduction pathway can significantly inhibit SW620 cell migration, during which the number of cell processes is reduced, and the length is shortened. ERK/MAPK signaling pathway may exert inhibition effect via inhibiting the cytoskeleton and cell processes. Zhang et al (19) also found a similar phenomenon. Najar et al (20) found that ERK signal transduction regulates the expression of cell transcription factor, causing cytoskeletal degeneration and enhancing invasion and metastasis capacities of tumor cells.

In conclusion, ERK/MAPK signaling pathway is involved in the effects of HGF on promoting proliferation and regulating cell cycle and apoptosis of human colon cancer cells, providing a new approach for the treatment of colon cancer.

\section{Acknowledgements}

Not applicable.

\section{Funding}

No funding was received.

\section{Availability of data and materials}

All data generated or analyzed during this study are included in this published article.

\section{Authors' contributions}

GZ and JY were responsible for CCK-8 assay. GZ and PS contributed to flow cytometry. All authors read and approved the final manuscript.

\section{Ethics approval and consent to participate}

The study was approved by the Ethics Committee of Chinese PLA General Hospital (Beijing, China).

\section{Patient consent for publication}

Not applicable. 


\section{Competing interests}

The authors declare that they have no competing interests.

\section{References}

1. Chen Y, Xie H, Gao Q, Zhan H, Xiao H, Zou Y, Zhang F, Liu Y and Li J: Colon cancer associated transcripts in human cancers. Biomed Pharmacother 94: 531-540, 2017.

2. Tahir AA, Sani NF, Murad NA, Makpol S, Ngah WZ and Yus of YA: Combined ginger extract \& Gelam honey modulate Ras/ERK and PI3K/AKT pathway genes in colon cancer HT29 cells. Nutr J 14: 31, 2015.

3. Ye J, Talaiti A, Ma Y, Zhang Q, Ma L and Zheng H: Allergies and risk of colorectal cancer: A systematic review and meta-analysis of observational studies. Oncotarget 8: 14646-14654, 2017.

4. Setia S, Nehru B and Sanyal SN: Upregulation of MAPK/Erk and PI3K/Akt pathways in ulcerative colitis-associated colon cancer. Biomed Pharmacother 68: 1023-1029, 2014.

5. Zhang Y, Yuan J, Zhang X, Yan F, Huang M, Wang T, Zheng X and Zhang M: Angiomotin promotes the malignant potential of colon cancer cells by activating the YAP-ERK/PI3K-AKT signaling pathway. Oncol Rep 36: 3619-3626, 2016.

6. Urosevic J, Nebreda AR and Gomis RR: MAPK signaling control of colon cancer metastasis. Cell Cycle 13: 2641-2642, 2014.

7. Dziegielewska B, Brautigan DL, Larner JM and Dziegielewski J: T-type $\mathrm{Ca}^{2+}$ channel inhibition induces p53-dependent cell growth arrest and apoptosis through activation of p38-MAPK in colon cancer cells. Mol Cancer Res 12: 348-358, 2014.

8. Zuo L, Yang X, Lu M, Hu R, Zhu H, Zhang S, Zhou Q, Chen F, Gui S and Wang Y: All-trans retinoic acid inhibits human colorectal cancer cells RKO migration via downregulating myosin light chain kinase expression through MAPK signaling pathway. Nutr Cancer 68: 1225-1233, 2016.

9. Gröschl B, Bettstetter M, Giedl C, Woenckhaus M, Edmonston T, Hofstädter F and Dietmaier W: Expression of the MAP kinase phosphatase DUSP4 is associated with microsatellite instability in colorectal cancer (CRC) and causes increased cell proliferation. Int J Cancer 132: 1537-1546, 2013.

10. Randhawa H, Kibble K, Zeng H, Moyer MP and Reindl KM: Activation of ERK signaling and induction of colon cancer cell death by piperlongumine. Toxicol In Vitro 27: 1626-1633, 2013.

11. Mao JD, Wu P, Huang JX, Wu J and Yang G: Role of ERK-MAPK signaling pathway in pentagastrin-regulated growth of large intestinal carcinoma. World J Gastroenterol 20: 12542-12550, 2014.
12. Zhao Y, Fan D, Zheng ZP, Li ET, Chen F, Cheng KW and Wang M: 8-C-(E-phenylethenyl)quercetin from onion/beef soup induces autophagic cell death in colon cancer cells through ERK activation. Mol Nutr Food Res 61: 1600437, 2017.

13. Radziwon-Balicka A, Santos-Martinez MJ, Corbalan JJ, O'Sullivan S, Treumann A, Gilmer JF, Radomski MW and Medina C: Mechanisms of platelet-stimulated colon cancer invasion: Role of clusterin and thrombospondin 1 in regulation of the P38MAPK-MMP-9 pathway. Carcinogenesis 35: 324-332, 2014.

14. Lee M, Young Kim S, Kim J, Kim HS, Kim SM and Kim EJ: Mitogen-activated protein kinase phosphatase-1 inhibition and sustained extracellular signal-regulated kinase $1 / 2$ activation in camptothecin-induced human colon cancer cell death. Cancer Biol Ther 14: 1007-1015, 2013.

15. Slattery ML, Lundgreen A and Wolff RK: Dietary influence on MAPK-signaling pathways and risk of colon and rectal cancer. Nutr Cancer 65: 729-738, 2013.

16. Enayat $S$, Ceyhan MŞ, Başaran AA, Gürsel M and Banerjee S: Anticarcinogenic effects of the ethanolic extract of Salix aegyptiaca in colon cancer cells: Involvement of Akt/PKB and MAPK pathways. Nutr Cancer 65: 1045-1058, 2013.

17. Chen B, Zeng X, He Y, Wang X, Liang Z, Liu J, Zhang P, Zhu H, $\mathrm{Xu} \mathrm{N}$ and Liang S: STC2 promotes the epithelial-mesenchymal transition of colorectal cancer cells through AKT-ERK signaling pathways. Oncotarget 7: 71400-71416, 2016.

18. Bodur C, Kutuk O, Karsli-Uzunbas G, Isimjan TT, Harrison P and Basaga $\mathrm{H}$ : Pramanicin analog induces apoptosis in human colon cancer cells: Critical roles for Bcl-2, Bim, and p38 MAPK signaling. PLoS One 8: e56369, 2013.

19. Zhang P, Kawakami H, Liu W, Zeng X, Strebhardt K, Tao K, Huang $S$ and Sinicrope FA: Targeting CDK1 and MEK/ERK overcomes apoptotic resistance in BRAF-mutant human colorectal cancer. Mol Cancer Res 16: 378-389, 2018.

20. Najar AG,Pashaei-Asl R, Omidi Y,Farajnia S and Nourazarian AR: EGFR antisense oligonucleotides encapsulated with nanoparticles decrease EGFR, MAPK1 and STAT5 expression in a human colon cancer cell line. Asian Pac J Cancer Prev 14: 495-498, 2013.

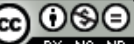

This work is licensed under a Creative Commons Attribution-NonCommercial-NoDerivatives 4.0 International (CC BY-NC-ND 4.0) License. 